\author{
Aksana Chmyha \\ - Belarusian State University \\ - e-mail: ch.ok.vas@gmail.com \\ - ORCID: 0000-0002-5793-3798
}

\title{
LEGAL RESTRICTIONS OF THE MEMBERS OF PARLIAMENTS OF BELARUS AND POLAND
}

\section{| Abstract}

- Goal - to analyse the key concepts of legal restrictions on the members of the Parliaments of Belarus and Poland in a comparative feature.

- Research methodology - the basis of the work is the comparative-legal method of research, as well as other methods of scientific inquiry.

- Score/results - there are significant obligations on Polish and Belarusian parliamentarians following from the requirements of legislative acts on the observance of a number of legal restrictions in the implementation of their mandates. In the article a number of progressive characteristics of legal restrictions on the members of the Parliaments of Belarus and Poland are stated.

- Originality/value - a new conclusion has been reached that it is preferable to further improve the regulatory framework that promotes the establishment of the legal restrictions of the members of Parliaments, which should be based both in Poland and in Belarus on the study and mutual implementation of the accumulated positive legislative experience of these states in this area.

| Keywords: legal restrictions, members of Parliaments, Parliament, Belarus, Poland, EU, comparative feature.

\section{Introduction}

The obligations of Polish and Belarusian parliamentarians to comply with a number of legal restrictions in the implementation of their mandates are significant. 
It is a general rule that legal norms in any developed state enshrine the following forms of limiting the rights and freedoms of a person and a citizen:

1) a ban on certain aspects of rights and freedom, that is, the establishment of boundaries of behaviour (relative ban);

2) a ban on the exercise of a right (freedom) in general (an absolute ban);

3) interference (intrusion) in a right (freedom) by authorized state bodies (characterized by active actions of state bodies and passive personal behaviour);

4) obligation;

5) responsibility [Podmarev, 2001: 39].

Meanwhile, in the catalogue of the above general legal restrictions, it is permissible to single out special "restrictions due to the peculiarities of the constitutional and legal status of certain categories of persons, the so-called professional restrictions... This means that the general restrictions on a citizen contained in constitutional legislation may be less than that on a person who holds an office" [Karasev, 2009: 135].

\section{The legal restrictions on the members of the Parliaments of Belarus and Poland}

Based on the foregoing and due to the fact that "the boundaries of the legally possible activity of people are established by the law which always limits human independence, replacing it with legally enshrined freedom" [Ageev, 2000: 52] the following professional legal restrictions for elected politicians - deputies of the House of Representatives, members of the Council of the Republic of the National Assembly of the Republic of Belarus - are enshrined in Belarusian legislation [On the status of a deputy...].

In particular, in Belarus one person cannot simultaneously be a member of two chambers of the Parliament of Belarus; a deputy of the House of Representatives cannot be a deputy of a local representative body - the local Council of Deputies; a member of the Council of the Republic cannot be simultaneously a member of the Government; it is also not allowed to combine the duties of a parliamentarian with the office of the President of the Republic of Belarus or a judge.

In addition, Belarusian parliamentarians are not entitled to: 
1) engage in entrepreneurial activity personally or through proxies, assist close relatives in the implementation of entrepreneurial activity by using their official position;

2) participate personally or through proxies in the management of a commercial organization (with some exceptions);

a) have accounts in foreign banks, with the exception of officials performing state functions in foreign states and other cases established by legislative acts;

3) engage in other paid work during working hours, except for teaching, scientific, cultural, creative activities, medical practice, carried out in agreement with the Chairman of the relevant chamber;

4) hold other public positions, except for the cases provided for by the Constitution of the Republic of Belarus and other legislative acts;

5) accept property (gifts) or receive other benefit in the form of a service in connection with the performance of official duties, with the exception of souvenirs awarded during protocol and other official events. Souvenirs received during protocol and other official events, the cost of which exceeds five basic units, become property of the state by decision of a commission created by the Chairman of the relevant chamber;

6) use for off-duty purposes the means of material, technical, financial and information support, other property of the relevant state body, and official secrets;

7) accept state awards of foreign states without the consent of the President of the Republic of Belarus.

In addition to the above, in accordance with the current Belarusian legislation [On the status of a deputy...], the exercise of the powers of a deputy of the House of Representatives, a member of the Council of the Republic on a professional basis is not allowed in the event of their close relationship (parents, spouses, children, siblings, as well as parents, children, siblings and sisters of spouses) with another civil servant, if their official activity is related to the direct subordination or control of one of them to the other.

One more significant legal restriction: a deputy of the House of Representatives, a member of the Council of the Republic is not allowed to receive from foreign states documents granting the rights to benefits and advantages in connection with their political views, religion, or nationality, as well as to use such benefits and advantages, unless it follows otherwise from international treaties of the Republic of Belarus. 
Moreover, a deputy of the House of Representatives, a member of the Council of the Republic, exercising their powers on a professional basis, are required to make a written commitment to comply with these restrictions.

Finally, as part of the obligation to comply with a number of restrictions in the implementation of mandates, Belarusian parliamentarians exercising their powers on a professional basis are also obliged to submit a declaration of income and property to the relevant chamber. This obligation is imposed on the spouse and adult close relatives (parents, children, adoptive parents, adopted children, siblings, grandfather, grandmother, grandchildren) living together and running a common household with the elected official. It should be emphasized that this duty of the Belarusian people's representatives is based on traditional European parliamentary procedures.

It is important to note that a deputy of the House of Representatives, a member of the Council of the Republic, exercising their powers on a professional basis, are subject to the provisions of the Law of the Republic of Belarus on Civil Service in the Republic of Belarus, and, therefore, legal restrictions arising from it.

Despite the fact that the aforementioned restrictions on the activities of members of the Parliament of Belarus are quite significant, we believe that in general they are quite justified, since "society needs tools to correctly restrict rights and freedoms. Restrictions on personal freedom are reasonable when they correspond to the level of political, legal and moral consciousness of people. A measure of legal restrictions can be found in public relations themselves. It is established objectively, although not without the influence of subjective factors" [Condorcet, 1936: 51].

Like the Belarusian one, the Polish legislator also provided for a fairly significant number of legal restrictions on the activities of members of Parliament in a number of normative legal acts. Thus, Article 102 of the Constitution of Poland contains a ban on simultaneous holding of the mandates of a deputy of the Sejm and a member of the Senate. In addition, in accordance with the current Polish national legislation, in particular, Article 103 of the Polish Constitution, a parliamentarian has no right to combine his mandate with the performance of the duties of:

- the Chairman of the National Bank of Poland and their deputies,

- the Chairman of the Supreme Chamber of Control and their deputies,

- the Commissioner for Human Rights and their deputies,

- the Commissioner for Children's Rights and their deputies, 
- a member of the Monetary Policy Council,

- a member of the National Broadcasting Council,

- an ambassador.

It is also prohibited to combine the mandate of a member of Parliament with functions in the Chanceries of the Sejm, the Senate, the President of the Republic or with work in government administration. This prohibition does not apply to members of the Council of Ministers and secretaries of state in the government administration.

Certain groups are not entitled to exercise a parliamentary mandate in Poland:

- judges,

- prosecutors,

- civil service employees,

- military personnel who remain in active military service,

- police officers,

- employees of the state security services (Article 103 of the Constitution of Poland).

In addition to the above, the members of the National Assembly of Poland are obliged to comply with other legal restrictions related to the implementation by these elected politicians of their parliamentary mandate. In particular, according to Article 30 of the law "On the Exercise of the Mandate of a Deputy and a Senator", Polish parliamentarians cannot be hired under the terms of an employment contract in a number of central state institutions (for example, in the offices of the National Broadcasting Council, the Constitutional Court of Poland, the Children's Rights Commissioner, and a number of other institutions), as well as local government offices. In addition, the mandate may be terminated if a parliamentarian occupies the position in the council of a borough (city), county and regional assemblies, as a voivode, mayor or president of a city, or as a member of the county or regional council. In addition, it is impossible to combine the posts of a deputy or a senator with the post of a Member of the European Parliament.

Article 107 of the Polish Constitution also prohibits members of Parliament from conducting economic activities benefiting from the property of the Treasury of the Polish state or local government as well as acquiring this property within the limits determined by law. 
Other legal restrictions related to the exercise of economic activity by holders of the mandate of a deputy of the Sejm or a member of the Senate of the National Assembly of Poland are enshrined in parts 2, 4 of Article 34 of the Polish act "On the Exercise of the Mandate of a Deputy and a Senator". Moreover, deputies of the Sejm and members of the Senate of the Polish state do not have the right to be the rightholders of a package of more than $10 \%$ of shares in commercial law companies with state or municipal participation. On the basis of this legal prohibition, Polish parliamentarians are obliged to alienate stocks or shares exceeding this limit before the first parliamentary session. In case of failure to comply with this requirement of the Polish legislator, during the period of the mandate and for two years after its termination, the elected persons in question do not have the right to participate in the exercise of their rights related to economic activities: the right to vote, the right to dividends, the right to division of property, the right to purchase shares (part 4 of Article 34 of the aforementioned act).

Polish law "On the Exercise of the Mandate of a Deputy and a Senator" also prohibits parliamentarians from engaging in any activity or receiving gifts that could undermine the confidence of voters in the implementation of the mandate (parts 1, 2 of Article 33). In order to ensure the proper fulfilment of this requirement of the legislator, the Sejm deputies and members of the Senate are obliged to notify the heads of the respective chambers of the Polish Parliament of their intention to engage in any activity, except for creative activity (related to the exercise of copyright) (part 1 of Article 33). We believe that this norm fulfils a significant anti-corruption role.

In addition to the above, the aforementioned Law within the framework of Article 35 imposes on the members of the Polish Parliament the obligation to submit a statement of their property status. Such a statement must contain information about:

1) monetary savings, real estate, shares and stocks in trading companies, the acquisition from the state treasury, another state legal entity or from territorial self-government units of property that were subject to alienation by auction, as well as data on economic activity and positions held in trading companies;

2) income received by virtue of the positions held, indicating the specific amount received for each position;

3) movable property worth over PLN 10,000;

4) monetary obligations in the amount exceeding PLN 10,000, including loans and loans received as well as the conditions under which they were received (part 1 of Article 35). 
This statement must also contain information regarding property jointly owned with spouses. It is noteworthy that giving false information in the application entails criminal liability on the basis of paragraph 1 of Article 233 of the Criminal Code of Poland.

In connection with the above, it should also be noted that the so-called Register of Material Benefits has been operating in the parliamentary system of Poland since 1997, within the framework of which members of the Houses of Parliament enter information on material benefits that they and their spouses received during the year. This is public information and is submitted for official publication once a year.

\section{Conclusions}

The author of this work believes that the specified anti-corruption experience of the Polish representative system can be used in the Belarusian state as well. In addition, in order to combat corruption and to avoid negative lobbying of laws, it is advisable to publish information about close relatives of parliamentarians, if they are engaged in entrepreneurial activities. It would be useful to establish normatively the norm according to which Belarusian parliamentarians would be obliged to provide annually information on their valuable movable and immovable property, bank deposits and securities. It seems necessary to supplement the normative list of restrictions on the activities of Belarusian parliamentarians by imposing on them the obligation to comply with the ban on receiving royalties for speeches and publications, the conduct and preparation of which are related to the implementation of their mandate.

\section{| References}

Ageev A.V., Ogranichenie prav i svobod grazhdan po Konstitucii Rossijskoj Federacii, dis. ... kand. yurid. nauk: 12.00.02, Moskva 2000 || Агеев А.В., Ограничение прав и свобод граждан по Конститучии Российской Федерации, дис. ... канд. юрид. наук: 12.00.02, Москва 2000.

Kondorse Zh.A., Eskiz istoricheskoj kartiny progressa chelovecheskogo razuma, Moskva 1936 || Кондорсэ Ж.А., Эскиз исторической картины прогресса человеческого разума, Москва 1936. 
Karasev A.T., Deputat v sisteme predstavitelnoj vlasti (konstitucionno-pravovoe issledovanie), dis. ... d-ra yurid. nauk: 12.00.02, Ekaterinburg 2009 || Карасев А.Т., Депутат в системе представительной власти (конституционно-правовое исследование), дис. ... д-ра юрид. наук: 12.00.02, Екатеринбург 2009.

O statuse deputata Palaty predstavitelej, chlena Soveta Respubliki Nacionalnogo Sobraniya Respubliki Belarus: Zakon Respubliki Belarus ot 4.01.1998 g. No. 196-Z: v red. Zakona Respubliki Belarus ot 17.07.2018 g, Konsultant Plyus: Belarus. Texnologiya 3000, [on-line], Nacionalnyj centr pravovoj informacii Respubliki Belarus, Minsk 2020 || О статусе депутата Палаты представителей, члена Совета Республики Национального Собрания Республики Беларусь: Закон Республики Беларусь от 4 ноября 1998 г. № 196-3: в ред. Закона Республики Беларусь от 17.07.2018 г., Консультант Плюс: Беларусь. Технология 3000, [электронный ресурс], Национальный центр правовой информации Республики Беларусь, Минск 2020.

Podmarev A.A., Konstitucionnye osnovy ogranicheniya prav i svobod cheloveka i grazhdanina $v$ Rossijskoj Federacii, dis. ... kand. yurid. nauk: 12.00.02, Saratov 2001 || Подмарев А.А., Конститучионные основы ограничения прав и свобод человека и гражданина в Российской Федерации, дис. ... канд. юрид. наук: 12.00.02, Саратов 2001. 